\title{
Opioid growth factor receptor is unaltered with the progression of human pancreatic and colon cancers
}

\author{
IAN S. ZAGON and PATRICIA J. McLAUGHLIN
}

\author{
Department of Neural and Behavioral Sciences, The Milton S. Hershey Medical Center, \\ The Pennsylvania State University, Hershey, PA, USA
}

Received January 23, 2006; Accepted March 21, 2006

\begin{abstract}
Opioid growth factor (OGF) is an endogenous opioid peptide ([Met $\left.{ }^{5}\right]$-enkephalin) that interacts with the OGF receptor (OGFr). OGF serves as a constitutively expressed and tonically active negative growth factor in neoplasia, and the OGF-OGFr axis contributes to the maintenance of an equilibrium in cell replication by targeting cyclin-dependent inhibitory kinase pathways. In a previous study, OGFr binding activity was found to decrease in concert with progression of human squamous cell carcinoma of the head and neck (SCCHN). To investigate the relationship of OGFr to advancement of human pancreatic and colon cancers, tumor cells were transplanted into nude mice, and small, medium, and large neoplasias were assessed for OGFr number and affinity by receptor binding analysis, and for gene expression of OGFr mRNA by Northern blot analysis. In addition, OGF levels were monitored in plasma. OGFr binding affinity and capacity, as well as transcriptional activity of OGFr, were not influenced by the size or state of differentiation of pancreatic or colon tumors. Plasma levels of OGF were 3.5- to 7.9-fold less in animals with pancreatic or colon cancers than in nude mice not receiving xenografts, and no differences in OGF values were recorded between small and large tumors. These data on human pancreatic and colon cancers, along with information in earlier studies on SCCHN, indicate that alterations in the OGF receptor are dependent on tumor type and that the integrity of the OGF-OGFr axis insofar as tumorigenesis needs to be evaluated for each type of neoplasm. This information will be relevant in the design of therapeutic modalities, the diagnosis and prognosis of neoplasia, as well as understanding of the processes and mechanisms of carcinogenesis.
\end{abstract}

Correspondence to: Dr Ian S. Zagon, Department of Neural and Behavioral Sciences, H109, The Penn State University College of Medicine, 500 University Drive, Room C3729, Hershey, PA 17033, USA

E-mail: isz1@psu.edu

Key words: opioid growth factor receptor, pancreatic cancer, colon cancer

\section{Introduction}

Opioid growth factor (OGF) and its receptor (OGFr) play a role in the regulation of growth of human cancer cells in tissue culture (1-5) and tumors in nude mice (6-9). OGF serves as a tonically active endogenous pentapeptide that inhibits cell proliferation in a receptor-mediated manner $(1-5,10)$. OGF action is unrelated to apoptosis/necrosis (11) or differentiation (12), and displays anchorage-independent properties (13). The mechanism of action of OGF appears to be the up-regulation of cyclin-dependent inhibitory kinases in order to delay the $\mathrm{G}_{0} / \mathrm{G}_{1}$ phase of the cell cycle (14). OGF and OGFr have been demonstrated by immunohistochemistry, radioimmunoassay, and/or receptor binding to be present in a variety of human and animal tumors and cancer cell lines (1-5,8,15-19). Immunoelectron microscopic studies $(20,21)$ reveal that OGFr resides on the outer nuclear envelope, where OGF interacts with OGFr, and the OGF-OGFr complex translocates between the cytoplasm and nucleus at the nuclear pore by interaction with karyopherin $B$. Thus, signal transduction for cell proliferation appears to involve an OGF-OGFr complex that interfaces with chromatin in the nucleus.

Clinical studies have documented specific and saturable binding of OGF in surgical specimens of pancreatic cancers (16), colon cancers (15), and squamous cell carcinoma of the head and neck (SCCHN) (17-19), indicating the presence of the OGF receptor. McLaughlin and colleagues (19) showed a 9-fold decrease in OGFr binding activity, and a 5-fold decrease in OGFr protein, from tumor tissue surgically removed from patients with SCCHN compared to normal epithelium; transcription of OGFr was comparable between SCCHN and normal samples. To fully examine the relationship of tumor progression and levels of OGFr, McLaughlin and Zagon (22) established an animal model of small, medium, and large SCCHN xenografts. These investigators found that OGFr binding capacity was 3- to 7-fold lower in large tumors of SCCHN than in small tumors, with no change in OGFr mRNA noted between small and large tumors. These results suggest that, at least for SCCHN, there is a progressive decrease in OGFr with advancement of neoplasia. Importantly, the results of this study in an animal model of SCCHN corroborate clinical findings.

The present study was designed to address the relationship of OGFr to tumor progression in other types of cancer known to have OGF receptor. Using 3 different pancreatic cancer cell 
lines, and 2 different colon cancer cell lines that represented poorly and well-differentiated cancers, subcutaneous tumors were collected from nude mice as 'small', 'medium', and 'large' in size (i.e., diameter, weight, volume). Receptor binding assays were performed to determine binding affinity $\left(\mathrm{K}_{\mathrm{d}}\right)$ and capacity $\left(\mathrm{B}_{\max }\right)$. Gene expression of OGFr was quantitated by densitometric analysis of Northern blots. Finally, to investigate the response of OGF levels in the plasma of animals with small, medium, and large tumors, radioimmunoassays were performed.

\section{Materials and methods}

Cancer cell lines. Three human pancreatic cancer cell lines (MIA PaCa-2, BxPC-3, and Capan-2) and 2 human colon adenocarcinoma cell lines (HT-29 and HCT 116) were used in this study. All cell lines were purchased from the American Type Culture Collection (Manassas, VA). The MIA PaCa-2 cell line was derived from an undifferentiated epithelial carcinoma occurring in the body and tail of the pancreas in a 65-year-old man (23). The BxPC-3 cell line originated from an adenocarcinoma of the body of the pancreas from a 61year-old female, and was characterized histologically as a moderately well to poorly differentiated adenocarcinoma (24). The Capan-2 cell line was derived by Fogh and Trempe from a well-differentiated adenocarcinoma in the head of the pancreas in a 56-year-old Caucasian male (26). The HT-29 cell line was derived from a well-differentiated primary colon adenocarcinoma that was established from a 44-year-old Caucasian female (26), whereas the HCT 116 cell line was derived from a poorly differentiated primary adenocarcinoma obtained from an adult male (27).

MIA PaCa-2 cells were maintained in Dulbecco's MEM (modified) media, HT-29 and HCT 116 were grown in McCoy's 5A media, and BxPC-3 and Capan-2 cells were cultured in RPMI. All media were supplemented with $10 \%$ fetal calf serum, $1.2 \%$ sodium bicarbonate, and antibiotics (5,000 units $/ \mathrm{ml}$ penicillin, $5 \mathrm{mg} / \mathrm{ml}$ streptomycin, $10 \mathrm{mg} / \mathrm{ml}$ neomycin). Cell cultures were maintained in a humidified atmosphere of $5 \% \mathrm{CO}_{2} / 95 \%$ air at $37^{\circ} \mathrm{C}$. The cells were harvested with $0.05 \%$ trypsin/ $0.53 \mathrm{mM}$ EDTA, centrifuged, and counted with a hemacytometer. Cell viability was determined by trypan blue staining.

Tumor cell implantation, tumor growth, and tissue collection. Male 4-to 5-week-old BALB/c-nu/nu nude mice, purchased from Harlan Laboratories (Indianapolis, IN), were housed in pathogen-free isolators in the Department of Comparative Medicine at the Penn State University College of Medicine. All procedures were approved by the IACUC committee of the Penn State University College of Medicine and conformed to the guidelines established by NIH. The mice were allowed at least 5 days to acclimate prior to beginning experimentation.

Nude mice received a single subcutaneous injection into the right scapular region of the following: $2 \times 10^{6}$ MIA $\mathrm{PaCa}-2,10^{6} \mathrm{BxPC}-3,3 \times 10^{6}$ Capan-2, 5x10 $10^{6} \mathrm{HT}-29$, and $10^{5}$ HCT 116 cells per mouse. For each cell line, at least 12 mice were utilized. Cell number was titrated to that which produced $100 \%$ tumors within approximately 2 weeks of cell inoculation.
Mice were observed daily for the initial appearance of tumors. Tumors were measured twice weekly using calipers. Tumor volume was calculated using the following formula: $\mathrm{w}^{2} \times 1 \times \pi / 6$, where the length is the longest dimension, and width is the dimension perpendicular to length (28). Tumors were harvested as small, medium, or large and corresponded to dimensions of approximately 10,20 , or $40 \mathrm{~mm}$, respectively, in one diameter.

When tumors were of the appropriate size, mice were euthanized by an overdose of sodium pentobarbital, and whole blood from some mice was collected into heparinized tubes from the heart. Plasma was separated from whole blood and stored at $-70^{\circ} \mathrm{C}$. Tumors were measured, removed and weighed. Tumor tissue was flash frozen in liquid nitrogen for receptor binding assays, frozen in isopentane chilled on dry ice for immunohistochemistry, or placed in guanidine isothiocyanate buffer (GIT) and stored at $-70^{\circ} \mathrm{C}$ for RNA assays. Tissues were processed within 2 weeks of collection.

Receptor binding assays. Dependent on tumor size, 1-3 tumors were sampled for each assay, and at least 3 binding assays were performed on each size tumor. Tumor tissues were removed, washed free of blood and connective tissue, immediately frozen in liquid nitrogen, and assessed following modifications of the procedures published previously $(8,9,17,29)$. Tumors were homogenized in $0.32 \mathrm{M}$ sucrose in Tris-buffer containing protease inhibitors (= Tris/all buffer). Nuclear protein homogenates were diluted with Tris/all buffer to the appropriate protein concentration and incubated at room temperature $\left(22^{\circ} \mathrm{C}\right)$ for $10 \mathrm{~min}$ to remove endogenous opioid peptides. Aliquots $(0.95 \mathrm{ml})$ of protein were incubated with $50 \mu \mathrm{l}$ of $\left[{ }^{3} \mathrm{H}\right]-\left[\mathrm{Met}^{5}\right]$-enkephalin (custom synthesized by Perkin-Elmer Life and Analytical Sciences, Boston, MA) and appropriate blockers. Non-specific binding was determined in the presence of $100 \mathrm{nM}$ unlabeled [Met $\left.{ }^{5}\right]$-enkephalin. Duplicate tubes of homogenates were assayed for each concentration. Protein concentrations were determined by the Bio-Rad method with gamma globulin as a standard.

Northern blot analysis of OGFr gene expression. OGFr gene expression was assessed for MIA PaCa-2 and HCT 116 tumors; at least 3 independent Northern blots/size/tumor, with each lane representing RNA from an individual tumor, were utilized. Total RNA was isolated from tumors by standard procedures (19). RNA was precipitated with ethanol and quantitated by UV spectrometry. Inasmuch as possible, equal amounts of total RNA were subjected to electrophoresis on $1 \%$ agarose- $2.5 \%$ formaldehyde gels. Northern blot analysis of OGFr gene expression was performed as described earlier (19). To control for differences in the amount of RNA loaded, as well as the integrity of the RNA, blots were stripped and reprobed with [ $\left.{ }^{32} \mathrm{P}\right]$-labeled cDNA for glyceraldehyde-3phosphate dehydrogenase (GAPDH).

Autoradiograms were analyzed for relative OD using a laser scanning densitometer (Molecular Dynamics/Amersham, Sunnyvale, CA) with PDQUEST software. The OD values for radiolabeled OGFr in individual blots were normalized to the OD values for GAPDH.

Measurement of OGF in plasma. OGF levels in plasma of mice with small, medium, and large MIA PaCa-2, BxPC-3, 


\section{Human Pancreatic Cancer}

Tumor Weight $(g)$

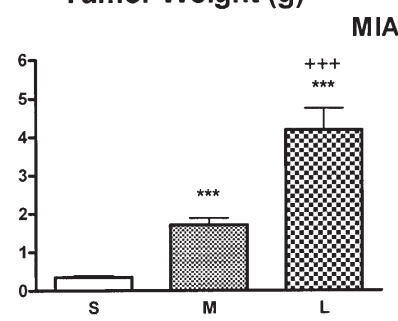

MIA PaCa-2

Tumor Volume $\left(\mathrm{mm}^{3}\right)$

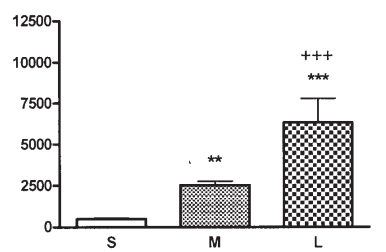

BxPC-3
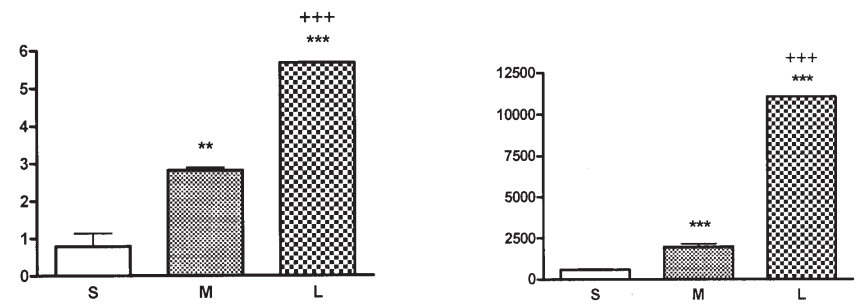

Capan-2
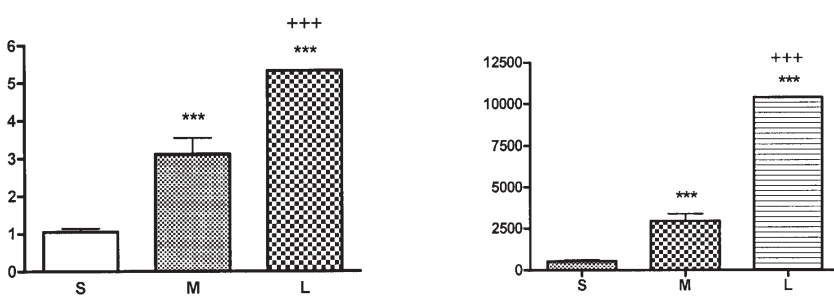

Figure 1. Tumor weight and tumor volume of small, medium, and large tumors derived from MIA PaCa-2, BxPC-3, and Capan-2 human pancreatic cancer cell lines. Data represent means \pm SEM for at least 10 tumors for each size. Significantly different from small tumors at ${ }^{* *} \mathrm{p}<0.01$ and ${ }^{* * *} \mathrm{p}<0.001$, and from medium tumors at ${ }^{+++} \mathrm{p}<0.001$.

and Capan-2 human pancreatic, and HT-29 colon adenocarcinoma, tumors were measured by standard radioimmunoassay procedures using a kit from Peninsula Laboratories (Belmont, CA).

Data analysis. Tumor weights and volumes, $\mathrm{B}_{\max }$ and $\mathrm{K}_{\mathrm{d}}$ values, and plasma OGF values were analyzed by analysis of variance (ANOVA); subsequent planned comparisons were made with Newman-Keuls tests. Data from binding assays were analyzed by GraphPad Prism 4.0 software; binding affinities and capacities, as well as Scatchard plots, were generated by the computer program.

\section{Results}

Body weight. Athymic nude mice weighed approximately $22 \mathrm{~g}$ at the beginning of experimentation. No significant differences were noted in the body weights of mice bearing small, medium, or large tumors within a tumor type, although mice with large tumors weighed slightly more, presumably due to the weight of the tumor. Thus, at the time of termination, mice with MIA PaCa-2, BxPC-3, and Capan-2 tumors had

\section{Human Colorectal Cancer}

Tumor Weight (g)

Tumor Volume $\left(\mathrm{mm}^{3}\right)$

HT -29

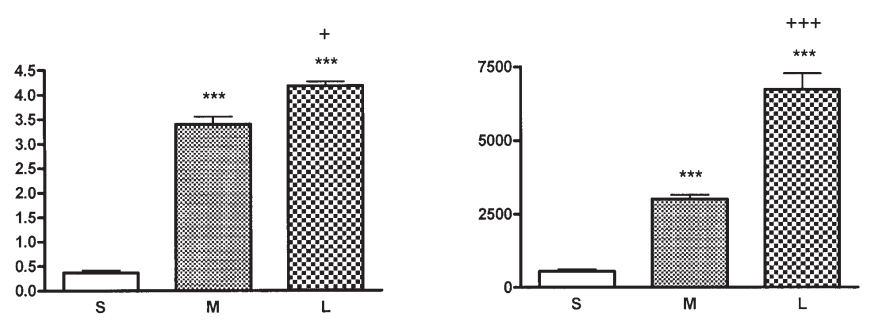

HCT 116
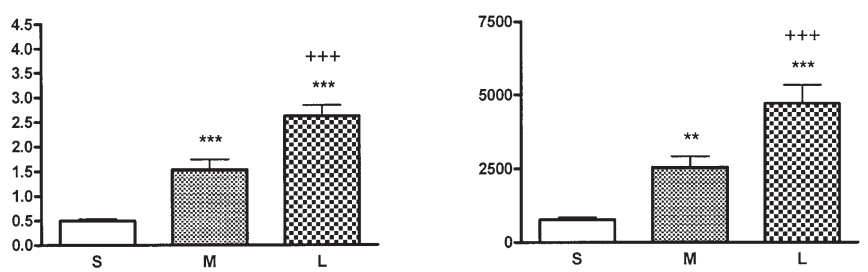

Figure 2. Tumor weight and tumor volume of small, medium, and large tumors derived from HT-29 and HCT 116 human colon cancer cell lines. Data represent means \pm SEM for at least 10 tumors for each size. Significantly different from small tumors at ${ }^{* *} \mathrm{p}<0.01$ and ${ }^{* * *} \mathrm{p}<0.001$, and from medium tumors at ${ }^{+} \mathrm{p}<0.05()$ and ${ }^{+++} \mathrm{p}<0.001$.

body weights of $28.0 \pm 1.2,31.8 \pm 1.6$, and $33.4 \pm 0.1 \mathrm{~g}$, respectively. Animals with HT-29 and HCT 116 tumors had body weights of $28 \pm 1.2$ and $24.6 \pm 0.7 \mathrm{~g}$, respectively.

Tumor volume and tumor weight. Weights and volumes of small, medium, and large tumors in mice receiving MIA PaCa-2, BxPC-3, or Capan-2 cells differed significantly (Fig. 1). For example, in the BxPC-3 group, the weights of medium and large tumors were 3.6- and 7.2-fold, respectively, greater than that of the small tumors, and the large tumors were 2.0-fold greater than those in the medium size group. Likewise, in the BxPC-3 group, tumor volumes for medium and large tumors were 3.3- and 18-fold, respectively, greater than that of small size tumors, and the large size tumors were 5.6-fold greater than those in the medium size group.

Weights and volumes of small, medium, and large tumors in mice receiving human colon cancer cell lines HT-29 or HCT 116 differed significantly (Fig. 2). For example, in the HCT 116 group, the weights of medium and large tumors were 3.0- and 5.2-fold, respectively, greater than that of the small size tumors, and the large tumors were $73 \%$ greater than those in the medium size group. Likewise, in the HCT 116 group, tumor volumes for medium and large tumors were 3.3- and 6.0-fold, respectively, greater than that of small tumors, and the large tumors were 1.8-fold greater than those in the medium size group.

OGFr receptor binding analyses. Radiolabeled OGF binding assays revealed specific and saturable binding of the ligand to OGFr, with binding curves that indicated a single site 
Table I. Binding affinity of $\left[{ }^{3} \mathrm{H}\right]-\left[\mathrm{Met}^{5}\right]$-enkephalin in nuclear homogenates of human pancreatic and colon cancer cells xenografted into nude mice.

\begin{tabular}{lrcr}
\hline & \multicolumn{3}{c}{ Tumor size } \\
\cline { 2 - 4 } $\begin{array}{l}\text { Cancer type } \\
\text { Cell line }\end{array}$ & Small & Medium & Large \\
\hline Pancreatic cancer & & & \\
MIA PaCa-2 & $1.5 \pm 0.4$ & $1.3 \pm 0.4$ & $2.2 \pm 0.6$ \\
BxPC-3 & $1.8 \pm 0.4$ & $1.9 \pm 0.7$ & $1.6 \pm 0.3$ \\
Capan-2 & $1.7 \pm 0.1$ & $2.2 \pm 0.6$ & $1.0 \pm 0.3$ \\
Colon & & & \\
adenocarcinoma & & & \\
HT-29 & $1.6 \pm 0.5$ & $1.0 \pm 0.3$ & $1.5 \pm 0.8$ \\
HCT 116 & $12.9 \pm 0.7$ & $7.3 \pm 2.1$ & $1.4 \pm 0.3$ \\
\hline
\end{tabular}

Values represent means \pm SEM for at least 3 assays. Data did not differ between any tumor size within each cancer cell line.

for each of the 3 pancreatic and 2 colon cancer cell lines examined.

Binding affinity. Binding affinity $\left(\mathrm{K}_{\mathrm{d}}\right)$ did not differ between assays for small, medium, and large tumors derived by inoculation with any of the pancreatic or colon cancer cell lines (Table I).

Binding capacity. Values for binding capacity $\left(\mathrm{B}_{\max }\right)$ for small, medium, and large tumors derived by inoculation with any of the pancreatic or colon cancer cell lines revealed no significant differences (Fig. 3).

OGFr gene expression. Quantitative analysis of OGFr gene expression as measured by RNA isolated from small, medium, or large MIA PaCa-2 pancreatic tumors or HCT 116 colon adenocarcinomas demonstrated similar expression profiles of OGFr normalized to GAPDH independent of tumor size (Fig. 4). Total RNA from MIA PaCa-2 or HCT 116 cells in culture was also analyzed for OGFr gene expression. Densitometric analysis of OGFr mRNA normalized to GAPDH revealed no differences in gene expression between cancer cells in vitro and small, medium, or large tumors (data not shown).

OGF levels in plasma. Serum levels of OGF in nude mice were assessed in blood collected at the time of death. OGF levels in mice with small or large tumors derived from MIA PaCa-2, Capan-2 or BxPC-3 pancreatic cancer cells did not differ (Fig. 5). No differences in serum OGF levels were detected in mice with small or large HT-29 colon tumors (Fig. 5). In comparison to plasma levels of OGF in nude mice never subjected to cancer cells, mice bearing pancreatic or colon tumors had significantly 3.4- to 7.9-fold less OGF; this difference in plasma OGF levels between mice with tumors, and those not inoculated with cancer cells, was $\mathrm{p}<0.001$.
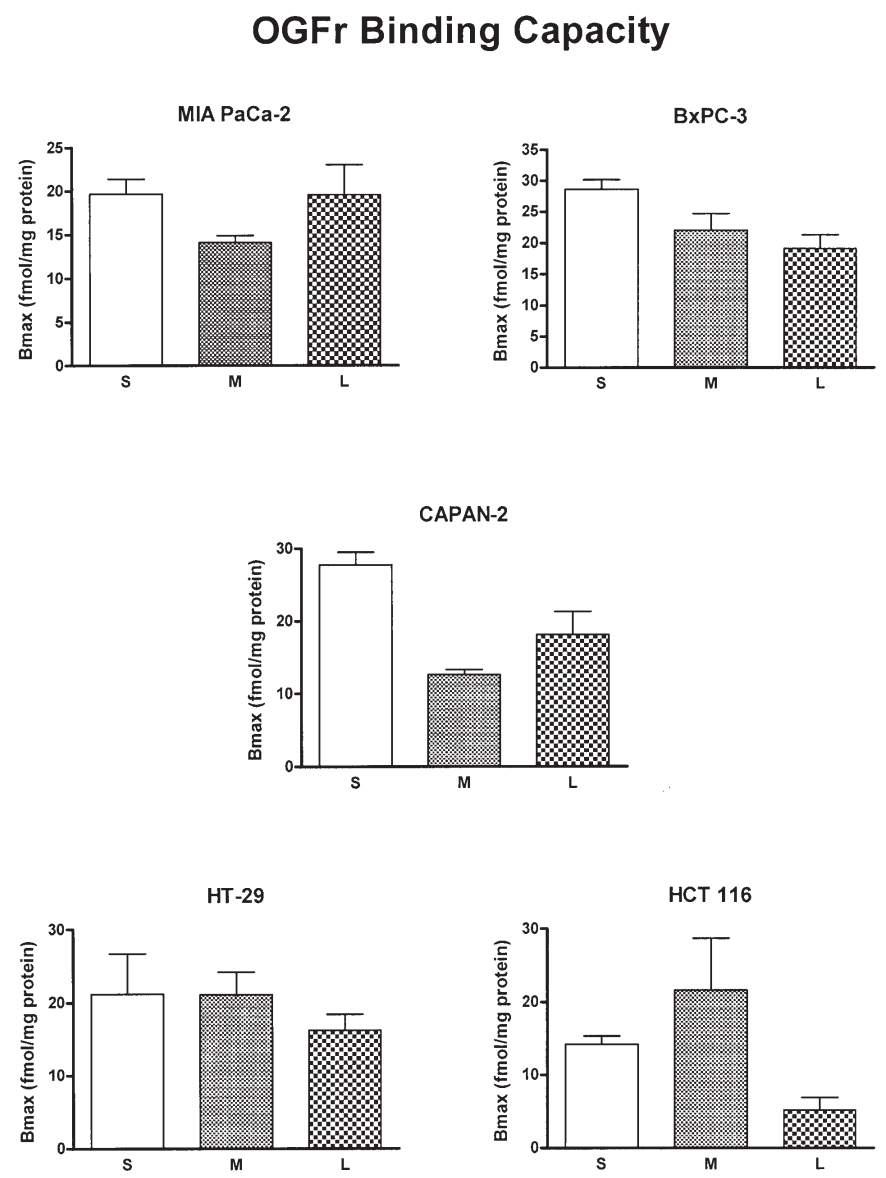

Figure 3. Binding capacity $\left(\mathrm{B}_{\max }\right)$ values of OGFr for small, medium, and large tumors derived from MIA PaCa-2, BxPC-3, Capan-2, HT-29, and HCT 116 cancer cell lines. Histograms represent means \pm SEM for at least 3 saturation binding isotherms. Data did not differ between any tumor size within each cancer cell line.
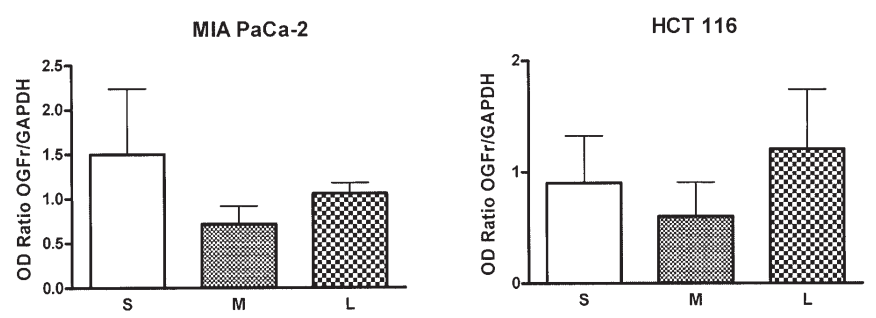

Figure 4. OGFr gene expression in specimens of small, medium, and large tumors derived from inoculation of nude mice with MIA PaCa-2 human pancreatic adenocarcinoma cells or HCT 116 human colon cancer cells. Northern blot analysis of total RNA isolated from tumors was probed with human OGFr cDNA; filters were stripped of isotope and reprobed with GAPDH, a constitutively expressed mRNA. The histogram presents optical density ratios. Values represent means \pm SEM. There were no statistical differences between tumors of various sizes in gene expression.

\section{Discussion}

Data generated in this study demonstrate that OGFr binding affinity and binding capacity, as well as transcriptional activity of OGFr, are not influenced by the size and, hence, progression of human pancreatic or colon cancer. The basis for this finding was our strategy to compare OGF receptor 


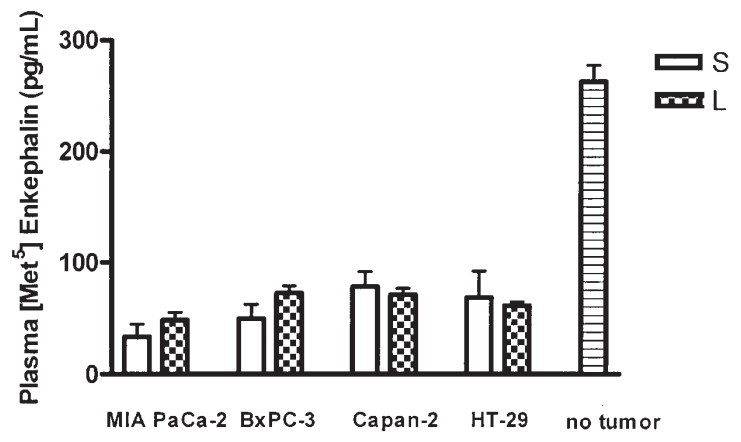

Figure 5. OGF levels in plasma of mice with small or large MIA PaCa-2, BxPC-3, Capan-2, and HT-29 tumors; plasma of athymic nude mice never inoculated with cancer cells was also evaluated (= no tumor). Values represent means \pm SEM. The plasma levels of OGF for all cancers (small and large) differed significantly from mice with no tumors.

binding kinetics $\left(\mathrm{K}_{\mathrm{d}}, \mathrm{B}_{\max }\right)$ and OGFr mRNA in tumors that were documented to be substantially different in diameter, weight, and volume. In addition, these results were consistent across cell lines within a cancer, and for two distinct cancer types. The use of pancreatic and colon cancer cell lines, representative of poorly to well-differentiated neoplasias (23-27), demonstrated that the magnitude of OGFr binding activity was not dependent on the state of differentiation. Thus, for the first time, our results with xenografts of human neoplasias show that progression of pancreatic and colon cancers are not associated with alteration in the OGF receptor.

The absence of changes in OGFr binding activity observed in this study contrasts with results documented by our lab (9-22) showing the relationship of OGFr to the progression of SCCHN. Previous reports by McLaughlin and Zagon (22) revealed that progression of SCCHN is accompanied by a decrease in the number of OGF receptors, and no change in binding affinity of OGFr or gene expression of OGFr mRNA. Comparison of the present observations, where no changes in OGF receptors were recorded for pancreatic and colon cancers, with those of SCCHN suggests that not all cancer types are affected similarly with respect to the OGF-OGFr axis.

In the present study, a systematic examination of the relationship of plasma levels of OGF in pancreatic and colon cancers was undertaken. The results show that mice with either cancer have markedly subnormal levels of OGF, regardless of the size of their tumor. Plasma levels of OGF have been reported previously for SCCHN (9-29), colon cancer (30), and pancreatic adenocarcinoma (7). When comparisons to nontumor animals were made, no changes in plasma OGF levels were observed with SCCHN (9-29), but animals with BxPC-3 pancreatic tumors had 4.4-fold more OGF in plasma than normal (non-tumor injected) mice (7). It is unclear why the data in the present study differ from those reported previously $(7,9,29)$. However, differences in radioimmunoassay kits and/or extraction procedures may account for this discrepancy. Data showing reductions in plasma OGF, along with a lack of change in OGF receptor number, with regard to cancer progression suggest that the events related to this peptide and receptor have to be considered separately.

The functional implications of a decrease in OGF levels toward cancer growth for pancreatic and colon neoplasia need to be considered. OGF is a tonically active inhibitory growth factor that interacts with OGFr to maintain a homeostatic equilibrium of cell replication. A decrease in OGF levels in the plasma of animals bearing pancreatic or colon cancer would suggest that there is a reduction in the amount of peptide required to optimally regulate DNA synthesis, with the result being an enhancement in tumor cell number. Indeed, antibody blockade of OGF activity in pancreatic cells, for example, markedly elevates the number of tumor cells from those treated with vehicle or non-immune $\operatorname{IgG}$ (3). Moreover, addition of exogenous OGF, either under in vitro $(3,29)$ or in vivo $(7,29)$ conditions, appears to compensate for the reduction in endogenous OGF.

The OGF-OGFr axis is important in the regulation of homeostatic cell proliferation, and the clinical implications of alterations in this system are of interest. The reduction in OGF levels in nude mice bearing human pancreatic and colon cancers would suggest that there is a defect in one element (i.e. OGF) of the OGF-OGFr axis. The net effect of a reduction in plasma OGF levels would be attenuation of the inhibitory action of this peptide, and an increase in cell replication and disease progression. As a corollary, administration of exogenous OGF would be expected to compensate for the loss of endogenous OGF because the receptor remains intact. Our studies support this hypothesis both in the laboratory $(1,3,6,7,29)$ and clinically $(30)$. Administration of exogenous OGF to patients with pancreatic cancer has successfully passed Phase I trials (30), and this study indicated that patients with unresectable pancreatic cancer receiving OGF had a marked increase in survival compared to historical controls.

\section{Acknowledgements}

This research was supported by grants from Philip Morris USA Inc. and Philip Morris International. We thank Jody Hankins and Caitlin Groff for their technical assistance.

\section{References}

1. Zagon IS, Hytrek SD and McLaughlin PJ: Opioid growth factor tonically inhibits human colon cancer cell proliferation in tissue culture. Am J Physiol 271: R511-R518, 1996.

2. McLaughlin PJ, Zagon IS and Skitzki J: Human neuroblastoma cell growth in tissue culture is regulated by opioid growth factor. Int J Oncol 14: 373-380, 1999.

3. Zagon IS, Smith JP and McLaughlin PJ: Human pancreatic cancer cell proliferation in tissue culture is tonically inhibited by opioid growth factor. Int J Oncol 14: 577-584, 1999.

4. McLaughlin PJ, Levin RJ and Zagon IS: Regulation of human head and neck squamous cell carcinoma growth in tissue culture by the opioid growth factor. Int J Oncol 14: 991-998, 1999.

5. Bisignani GJ, McLaughlin PJ, Ordille SD, Jarowenko MJ and Zagon IS: Human renal cell proliferation in tissue culture is tonically inhibited by opioid growth factor. J Urol 162: 2186-2191, 1999.

6. Zagon IS, Hytrek SD, Lang CM, Smith JP, McGarrity TJ, Wu Y and McLaughlin PJ: Opioid growth factor ([Met $\left.{ }^{5}\right]$-enkephalin) prevents the incidence and retards the growth of human colon cancer. Am J Physiol 271: R780-R786, 1996.

7. Zagon IS, Hytrek SD, Smith JP and McLaughlin PJ: Opioid growth factor (OGF) inhibits human pancreatic cancer transplanted into nude mice. Cancer Lett 112: 167-175, 1997.

8. McLaughlin PJ, Levin RJ and Zagon IS: Opioid growth factor (OGF) inhibits the progression of human squamous cell carcinoma of the head and neck transplanted into nude mice. Cancer Lett 199: 209-217, 2003 
9. McLaughlin PJ, Stack BC, Braine KM, Ruda JD and Zagon IS: Opioid growth factor (OGF) inhibition of a human squamous cell carcinoma of the head and neck in nude mice: dependency on the route of administration. Int J Oncol 24: 227-232, 2004

10. Zagon IS, Roesener CD, Verderame MF, Ohlsson-Wilhelm BM, Levin RJ and McLaughlin PJ: Opioid growth factor regulates the cell cycle of human neoplasias. Int J Oncol 17: 1053-1061, 2000.

11. Zagon IS and McLaughlin PJ: Opioids and the apoptotic pathway in human cancer cells. Neuropeptides 37: 79-88, 2003.

12. Zagon IS and McLaughlin PJ: Opioids and differentiation in human cancer cells. Neuropeptides 39: 495-505, 2005.

13. Zagon IS and McLaughlin PJ: Opioid growth factor (OGF) inhibits anchorage-independent growth in human cancer cells. Int J Oncol 24: 1443-1448, 2004.

14. Cheng F, Zagon IS, Verderame MF and McLaughlin PJ: OGFOGFr axis and its inhibitory actions on cell cycle progression of head and neck cancer cell line SCC1. Mol Biol Cell 16: 77, 2005.

15. Hytrek SD, Smith JP, McGarrity TJ, McLaughlin PJ, Lang CM and Zagon IS: Identification and characterization of the $\zeta$-opioid receptor in human colon cancer. Am J Physiol 271: R115-R121, 1996.

16. Zagon IS, Smith JP, Conter R and McLaughlin PJ: Identification and characterization of opioid growth factor receptor in human pancreatic adenocarcinoma. Int J Mol Med 5: 77-84, 2000.

17. McLaughlin PJ, Levin RJ and Zagon IS: The opioid growth factor receptor (OGFr) in human head and neck squamous cell carcinoma. Int J Mol Med 5: 191-196, 2000

18. Levin RJ, Wu Y, McLaughlin PJ and Zagon IS: Expression of the opioid growth factor, $\left[\mathrm{Met}^{5}\right]$-enkephalin, and the zeta opioid receptor in head and neck squamous cell carcinoma. Laryngoscope 107: 335-339, 1997.

19. McLaughlin PJ, Stack BC, Levin RJ, Fedok F and Zagon IS: Defects in the OGF receptor (OGFr) in human squamous cell carcinoma of the head and neck. Cancer 97: 1701-1710, 2003.

20. Zagon IS, Ruth TB, Leure-DuPree AE, Sassani JW and McLaughlin PJ: Immunoelectron microscopic localization of the opioid growth factor receptor (OGFr) and OGF in the cornea. Brain Res 967: 37-47, 2003.
21. Zagon IS, Ruth TB and McLaughlin PJ: Nucleocytoplasmic distribution of opioid growth factor (OGF) and its receptor (OGFr) in tongue epithelium. Anat Rec 282: 24-37, 2005.

22. McLaughlin PJ and Zagon IS: Progression of squamous cell carcinoma of the head and neck is associated with downregulation of the opioid growth factor receptor (OGFr). Int $\mathbf{J}$ Oncol 28: 1577-1583, 2006.

23. Yunis AA, Arimura GK, Russin DJ: Human pancreatic carcinoma (MIA $\mathrm{PaCa}-2$ ) in continuous culture: sensitivity to asparaginase. Int J Cancer 19: 128-135, 1977.

24. Tan MH, Nowak NJ, Loor R, Ochi H, Sandberg AA, Lopez C, Pickren JW, Berjian R, Douglass HO and Chu TM: Characterization of a new primary human pancreatic tumor line. Cancer Invest 4: 15-23, 1986.

25. Kyriazis AA, Kyriasis AP, Sernberg CN, Sloane NH and Loveless JD: Morphological, biological, biochemical, and karyotypic characteristics of human pancreatic ductal adenocarcinoma Capan-2 in tissue culture and the nude mouse. Cancer Invest 46: 5810-5815, 1986.

26. Fogh J and Trempe G: New human tumor cell lines. In: Human Tumor Cells In Vitro. Fogh J (ed). Plenum Press, New York, pp115-119, 1975.

27. Brattain MG, Fine WD, Khaled FM, Thompson $\mathrm{J}$ and Brattain DE: Heterogeneity of malignant cells from a human colonic carcinoma. Cancer Res 41: 1751-1756, 1981.

28. Shim WSN, Teh M, Mack POP and Ge R: Inhibition of angiopoietin-1 expression in tumor cells by antisense RNA approach inhibited xenograft tumor growth in immunodeficient mice. Int J Cancer 94: 6-15, 2001.

29. Jaglowski JR, Zagon IS, Stack BC, Verderame MF, LeureDuPree AE, Manning JD and McLaughlin PJ: Opioid growth factor (OGF) enhances tumor growth inhibition and increases the survival of paclitaxel-treated mice with squamous cell carcinoma of the head and neck. Cancer Chemother Pharmacol 56: 97-104, 2005

30. Hytrek SD, McLaughlin PJ, Lang CM, and Zagon IS: Inhibition of human colon cancer by intermittent opioid receptor blockade with naltrexone. Cancer Lett 101: 159-164, 1996.

31. Smith JP, Ahmad M, Conter R, Bingaman S, Harvey H, Mauger D, Demers L, McLaughlin PJ, Stanley W and Zagon IS: Treatment of advanced pancreatic cancer with opioid growth factor. Anticancer Drugs 15: 203-209, 2004. 